\title{
Over 50 Years of Potato Parental Line Breeding Programme at the Plant Breeding and Acclimatization Institute in Poland
}

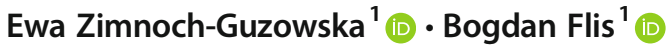

Received: 9 September 2020 / Accepted: 3 March 2021 / Published online: 21 May 2021

(C) The Author(s) 2021

\begin{abstract}
The paper describes the potato parental line breeding programme developed in Poland from the 1960s. The aim of the programme was to create parental forms useful for speeding up the breeding of new potato varieties and getting higher efficiency in directed selection for desired traits. The programme introduced new sources of resistance and quality traits into the Polish breeding pool by conducting research and breeding of tetraploid and diploid parental lines. The programme had significant impact on potato breeding, with 72 Polish potato varieties originating from crossings involving parental lines. These varieties show higher levels of resistance to major pathogens of potato crops, including resistance to Potato virus $\mathrm{Y}$ and late blight in starch group. Besides the direct impact on potato breeding, the programme was the stimulus for developing studies focused on potato genotype.
\end{abstract}

Keywords Diploid potato $\cdot$ Parental lines $\cdot$ Potato breeding $\cdot$ Resistance to pathogens

\section{Introduction}

The article is a summary of the programme of potato parental line breeding initiated by professor Kazimierz Świeżyński in 1961, before the Młochów Research Center of the Potato Research Institute was created, and then since 1966 fully developed at this centre for over 50 years. At the time when the programme was started, the most outstanding features of potato production in Poland were the large potato growing area (ca 2.8 million ha) with a harvest of 43 million tonnes a year, which was many times larger than today; the high human consumption (ca. $200 \mathrm{~kg} /$ person/year); approximately $50 \%$ of potato harvest used for animal feed; and lack of processed products with the

Bogdan Flis

b.flis@ihar.edu.pl

$1 \quad$ Plant Breeding and Acclimatization Institute - National Research Institute, Research Centre Młochów, Platanowa 19, 05-831 Młochów, Poland 
exception of starch production. Thus, the potato varieties grown at the time were mostly suitable for general use. After World War II, the material foundations of potato breeding, including plant materials, had to be practically rebuilt. Therefore, an urgent need was to increase the scale and speed of variety breeding resulting in new varieties for potato producers.

Tetraploidy of cultivated potato Solanum tuberosum L. ( $t b r$ ) hinders the breeding process. During the selection process, the breeder assesses the breeding material in terms of about 50 qualitative, resistance, or agronomic traits, usually independently inherited. It became increasingly difficult to select recombinants in the offspring of tetraploid parents that meet the requirements of the modern variety. Therefore, typically one variety has been selected from around 100,000 clones (Ross 1986) over 11-12 years.

The aim of the programme was to create parental breeding lines useful for speeding up the breeding of new varieties and getting higher efficiency in directed selection for desired traits. According to Świeżyński (1971), the tetraploid parental line (TPL) had to widen the genetic pool available for breeders. TPL is defined as a clone that has high levels of some important traits and after one cross with another partner is able to create the offspring from which a new variety can be selected directly (Świeżyński 1971). It was assumed that all parental lines should be characterized by acceptable tuber yield and tuber appearance and a not too long vegetation period. These basic requirements were the background to some distinguishing traits of specific TPL. The distinguishing traits were related to the specific direction of crop utilization or to specific conditions of its cultivation, such as (1) good cooking quality, (2) earliness in table and starch varieties, (3) high starch and protein content, (4) suitability for light soils with water deficiency, and (5) good processing quality. Taking into account the level of crop cultivation at that time, it was also assumed that future varieties resulting from crossing with TPLs would be characterized by a high level of resistance to important diseases or pests, among which were virus diseases, late blight, storage diseases, and nematodes. These resistances were rare or not identified in the breeding pool available at that time. The programme was realized in two ways using tetraploid and diploid materials. The diploid potatoes were considered the sources of new resistances not present in the pool of tetraploid varieties. However very soon, diploid materials were recognized as valuable source of quality traits as well.

\section{The Selection Scheme}

One of the basic ideas in parental line breeding is to develop new breeding lines in the shortest possible time while maintaining the requirement for the most complete and accurate characterization of the traits. In fact, the parental lines were produced in 6-year cycles of pre-breeding (Table 1). The necessary high multiplication rate already at the initial stage of breeding was ensured by the field propagation of the first year seedlings. The individuals of the second vegetative generation were tested in field experiments in which tuber yield, tuber morphology, starch content, and culinary quality were assessed (Domański 2001a, b). Until the mid-1980s, the most advanced tetraploid parental lines were tested in three locations, and for the group of parental lines for light soil cultivation, the field trials in the 4th and 5th year were carried out on sandy, water- 
Table 1 Basic (simplified) selection scheme for TPL breeding

\begin{tabular}{|c|c|c|c|c|c|c|}
\hline \multirow[t]{4}{*}{ Evaluations/testing } & \multicolumn{6}{|l|}{ Year } \\
\hline & 1 & 2 & 3 & 4 & 5 & 6 \\
\hline & \multirow[t]{2}{*}{ Crossings } & \multirow{2}{*}{$\begin{array}{l}\text { Field-grown } \\
\text { seedlings }\end{array}$} & \multicolumn{4}{|c|}{ Vegetative generation } \\
\hline & & & $\begin{array}{l}\text { Seedling's } \\
\text { lines }\end{array}$ & $\begin{array}{l}\text { New } \\
\text { lines }\end{array}$ & $\begin{array}{l}\text { Young } \\
\text { lines }\end{array}$ & $\begin{array}{l}\text { Advanced } \\
\text { lines }\end{array}$ \\
\hline $\begin{array}{l}\text { Agronomic traits in field } \\
\text { trials with replications }\end{array}$ & na & na & na & Yes & Yes & Yes \\
\hline Viruses resistance & na & $\mathrm{mi}$ & $\mathrm{mi}$ & $\mathrm{mi} /$ graft & Graft & Graft/aphid \\
\hline Resistance to $\mathrm{LB}^{\S}$ & na & na & 1 & $1 / \mathrm{t}$ & $1 / t / f$ & $1 / t / f$ \\
\hline $\begin{array}{l}\text { Resistance to nematodes, } \\
\text { wart, and soft } \operatorname{rot}^{\dagger}\end{array}$ & na & na & na & Ro1/D1 & Ro1/D1 & Soft rot \\
\hline
\end{tabular}

\# mi/graft/aphid - mechanical inoculation (resistance to PVX, PVY, or PVM), graft inoculation (resistance to PVY, PVM, and PVS), aphid inoculation (resistance to PLRV)

$\S \mathrm{LB} 1 / \mathrm{t} / \mathrm{f}$ - testing for resistance to late blight in leaflet test/tuber slice test/field test

$\dagger$ Ro1/D1 - testing for resistance to pathotype Ro1 of Globodera rostochiensis/pathotype D1 of Synchytrium endobioticum

na not applicable at this stage

deficient soil. However, the breeding of tetraploid parental lines for light soils ceased in the mid-1990s due to limited funding.

In the mid-1990s, work commenced on parental lines suitable for processing. The routine selection of such lines (mainly suitable for chipping) involved screening for chipping quality of tubers from various storage condition, namely after 3 months of storage at $10{ }^{\circ} \mathrm{C}$, directly after 5 months of cold storage $\left(4^{\circ} \mathrm{C}\right)$, and after 5 months of storage at $4{ }^{\circ} \mathrm{C}$ followed by 2 weeks of reconditioning at $18{ }^{\circ} \mathrm{C}$.

The distinctive feature of the parental line breeding programme was applying high selection pressure in the shortest possible time. The selection of genotypes resistant to viruses started at the stage of very young first-year seedlings by applying spray inoculation of some viruses and visual selection before planting in the field (Sieczka 2001a). The selection at this stage was severe, since ca. $10 \%$ of field-grown seedlings were collected after visual evaluation of yield and tuber appearance. In the following generations, resistance to pathogens and pests was extensively screened in greenhouse and laboratory tests (Syller 2001; Wasilewicz-Flis 2001; Chrzanowska 2001; Zarzycka 2001; Lebecka 2001; Pietrak 2001; Sieczka 2001b). In the case of virus resistance, such tests were naturally supported by the location of the experimental field in a region with a high viral pressure.

The selection of resistant individuals was based on the identification of genotypes that remained healthy after artificial inoculation with a specific pathogen (Table 1 shows a simplified scheme of selection of resistant genotypes; the details are given by Flis (2017)). However, in the last period of the parental line programme, selection based on the genotype began to replace phenotypic tests, although in some cases, mixed phenotypic and marker-assisted selection was considered best (Flis 2017). 
For the diploid programme, the screening and evaluation scheme was essentially the same as for tetraploids, with some modifications such as evaluation in non-replicated field trials at one location.

The best parental lines or advanced lines distinguished only by the desired traits in a specific crossing programme were used in the next cycle of recombination breeding to generate progenies for selecting new lines. This was crucial for rapid development of parental lines with multiple (complex) resistances.

\section{Diploid Parental Line Breeding}

In 1968, a diploid parental line (DPL) breeding programme was initiated to complement the TPL programme, and the first diploid seedlings were grown in 1970. The programme was based on the following considerations.

a. Diploid wild and primitive cultivated Solanum species are rich sources of resistance and quality traits and widen the genetic variation useful for potato breeding. In addition, many of these species are relatively easily crossed with dihaploids of S. tuberosum varieties or breeding lines.

b. The disomic inheritance is much simpler than tetrasomic inheritance.

c. Homozygous parental lines producing non-segregating progenies for desired traits should be easier to achieve in diploids than in tetraploids (Świeżyński et al. 1985).

d. The use of $2 n$ gametes (genetically first (FDR) or second (SDR) division restitution) allows the transfer of $2 x$ potential to $4 x$ level via interploid crosses ( $4 x-2 x$ or $2 x-4 x$ ) (Iwanaga 1982; Zimnoch-Guzowska and Dziewońska 1989).

\section{Diploid Parental Lines (DPL)}

The above assumptions determined the methods of diploid exploitation by various research and breeding centres (Chase 1963; Mendinburu and Peloquin 1977; Wenzel et al. 1979). The diploid breeding programme at the Młochów Center was implemented in several stages (Fig. 1). In the early 1970s, preselection was initiated in wild $2 x$ Solanum species to maximize chosen quality or resistance traits, assuming an increase of homozygosity of the breeding lines. In parallel, the haploidization of several Polish varieties and $4 x$ breeding lines was done via pollination with haploid inducers from $S$. phureja. The resulting putative dihaploids were screened for ploidy level and then preselected for agronomic traits and fertility. Next, chosen lines of wild Solanum were crossed with the dihaploids of $S$. tuberosum. The next steps involved several consecutive crossing and selection cycles that produced diploid genotypes with increasing complexity of resistance traits, better quality, and reduced negative influences from wild ancestors. After 5-7 cycles of crossing and selection, the DPLs were complex interspecific hybrids. In the last stage of the diploid programme, the switch from $2 x$ to $4 x$ level was achieved by interploid $4 x-2 x$ crosses, provided the diploid parent produced $2 n$ male gametes. The frequency of $2 n$ gametes, identified as large pollen grains, was variable among diploid lines and averaged about 22\% (Strzelczyk-Żyta et al. 1997). Selected diploids varied in their mechanism of $2 n$ gamete formation: FDR or SDR. Due 


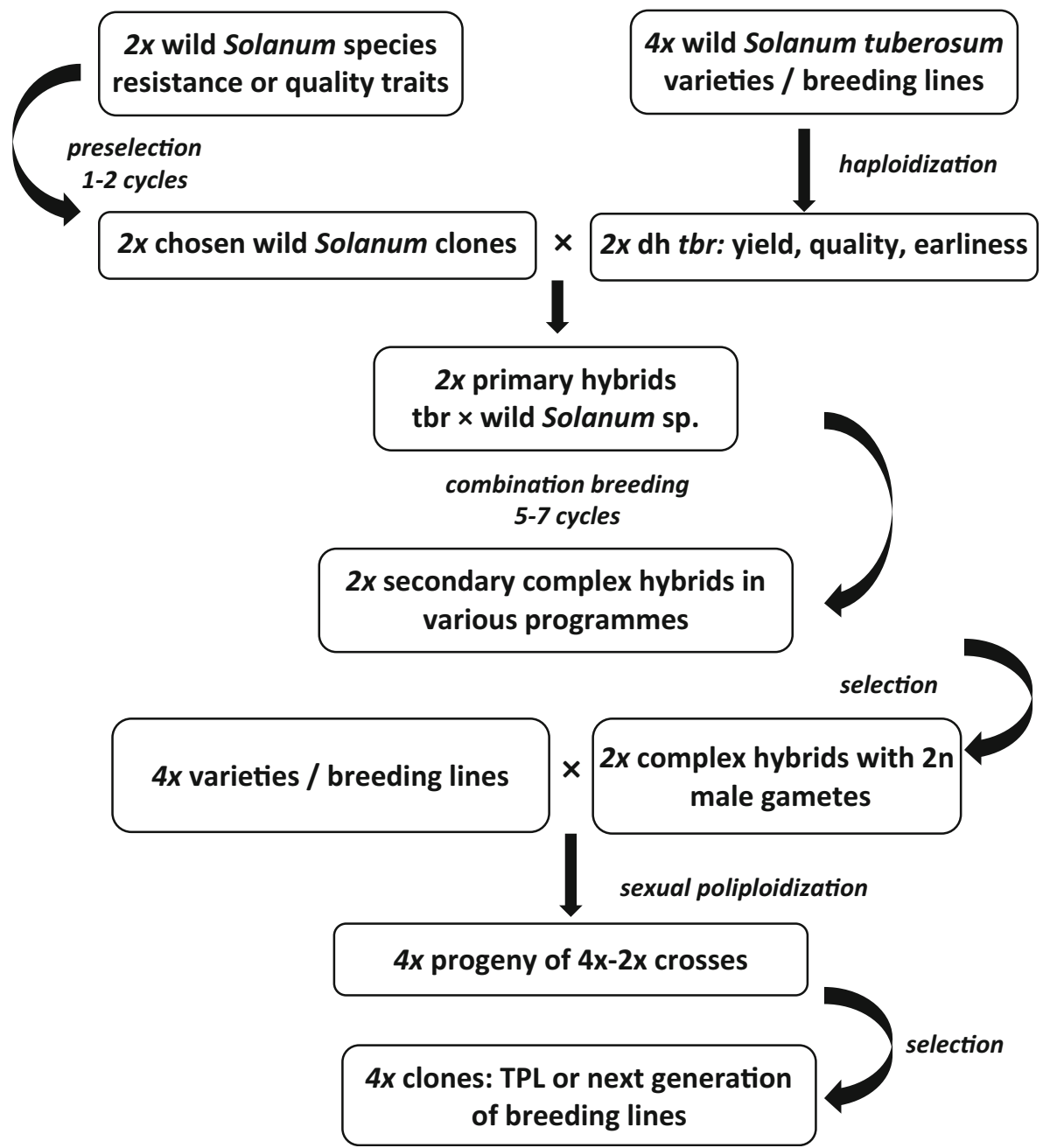

Fig. 1 The scheme of diploid potato breeding and its application at IHAR Młochów Research Center in the years 1970-2013

to inhibited recombination, the gene combinations in interspecific hybrids producing $2 n$ gametes by FDR were transferred nearly intact to their progenies in $4 x$ - $2 x$ crosses. This allowed the transmission of both general and specific combining effects to the tetraploid progenies (Mendiburu and Peloquin 1977; Wagenvoort and Zimnoch-Guzowska 1992; Lebecka et al. 2004). It was supported by the significantly higher frequency of desirable $4 x$ recombinants found in the offspring of $4 x$ - $2 x$ crosses than those of $4 x-4 x$ crosses (Zimnoch-Guzowska and Wasilewicz 1987; Domański et al. 2000). We recognized as important the necessity to increase the level of seed setting in $4 x-2 x$ crosses, which should facilitate the use of DPLs in breeding programmes of $4 x$ varieties. 


\section{Directions of Breeding DPL}

The directions of diploid programmes were modified over the years (Fig. 2). The oldest ones focused on selection of DPLs with the high starch content of tubers and high starch yield and two supporting subprogrammes: (1) selection of diploids resistant to main potato viruses: potato leafroll virus (PLRV), potato virus Y (PVY), potato virus $\mathrm{M}$ (PVM), potato virus $\mathrm{X}(\mathrm{PVX})$, and potato virus $\mathrm{S}$ (PVS) and (2) diploids resistant to late blight (LB). In 1982, the programmes of DPL breeding for high table value and for chipping quality arose using materials selected for early starch yield combined with resistances to pathogens. Special attention was paid to a support subprogramme with a specific goal for DPLs to enhance ability to form $2 n$ gametes. The most recent subprogramme was dedicated to DPLs resistant to the pectinolytic bacteria Pectobacterium sp. and Dickey sp., the causative agents of blackleg and soft rot of tubers. It has been developed since 1995 and based on high starch diploids (ZimnochGuzowska and Łojkowska 1993).

The IHAR diploid programme in 1970s and 1980s was one of the largest in the world (Świeżyński and Zimnoch-Guzowska 1996). In the years 1970-2008, up to 20,000 first-year seedlings and up to $17002 x$ clones were field grown, with an average of about 7000 seedlings and ca. 800 clones a year. The scale of work was somewhat reduced after 1995 due to the reduction of research funding.

In the programme for high starch content of tubers, several diploid hybrid clones were selected in which starch content reached up to 30\% (Zimnoch-Guzowska and Łojkowska 1993). As sources of high starch content in tubers, among others, Solanum species of the Commersoniana series and S. verrucosum have been used. Other goals for starch clones were (1) to shorten vegetation period (by crossings to early yielding dihaploids tbr or diploids), (2) to enhance starch yield through higher tuber yield, and (3) to reduce the content of glycoalkaloids in tubers.

Main programmes in diploid breeding
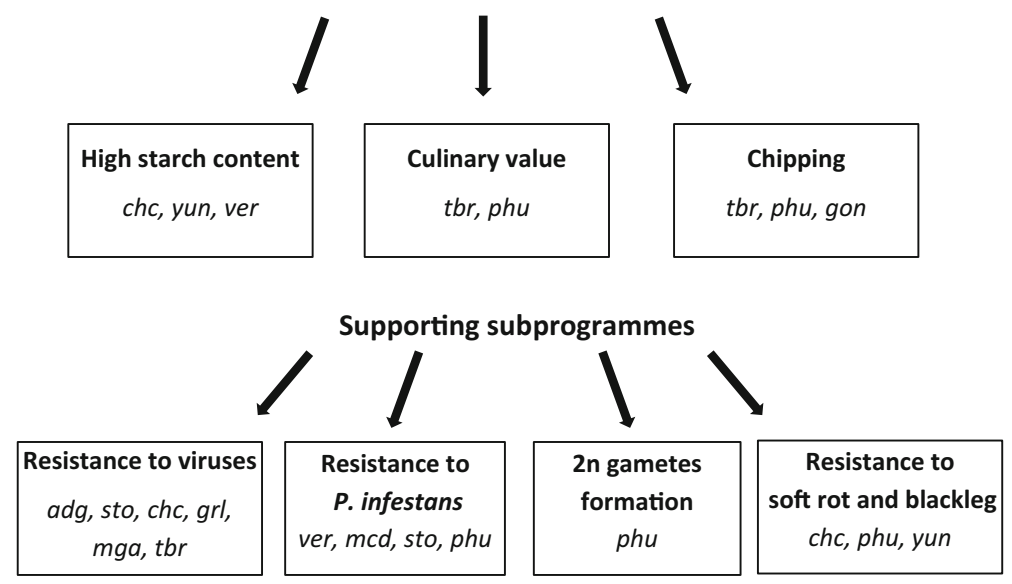

Fig. 2 Main and supporting programmes of DPL breeding at IHAR-PIB and main Solanum resources applied (abbreviations of the names of Solanum species acc. Huaman and Ross 1985) 
The developments of diploids outstanding in table quality and in chipping quality were the next two main directions of the diploid programme. Additional desirable characters were an ability to form $2 n$ gametes and good level of agronomic traits combined with resistances to potato pathogens. All selection and evaluation procedures applied to this group of material were the same as those used for tetraploids (see Table 1). Diploids outstanding in a low accumulation of reducing sugars after cold storage have been selected (Jakuczun et al. 1995). For diploid clones with high table quality, additional attention was paid to the evaluation of blackening of fresh and cooked tuber flesh (Jakuczun and Eising 2003) and tendency of tuber greening under light exposure (Jakuczun and Zimnoch-Guzowska 2006).

The development of diploid lines originating from various late blight resistance sources was the aim of the subprogramme for breeding LB-resistant diploids (ZimnochGuzowska 2009). The first selections were based on five sources: $S$. verrucosum (ver PI 1195170 and CPC 2644), S. microdontum (WAC 3220), S. phureja (Soliman CCC 1.3), and S. phureja $\times$ S. stenotomum carrying Rpi-phul gene (Śliwka et al. 2006). Additional sources introduced into DPL resistant to LB were $S$. michoacanum (including the Rpi-mchl gene, acc. Śliwka et al. 2012a) and S. ruiz-ceballosii (including the Rpi-rzcl gene acc. Śliwka et al. 2012b), obtained from the N.I. Vavilov Research Institute for Plant Industry (VIR), Russia (Zoteyeva et al. 2012).

The oldest $2 x$ subprogrammes included the one aimed at the breeding of DPLs with complex resistance to economically important viruses in Poland, i.e., PVY, PRLV, PVM, PVS, and those of lesser importance, such as PVX and PVA. This programme was parallel to the virus-resistant TPL breeding. Within the programme, two different types of resistance to PVM were found in $S$. megistacrolobum and $S$. gourlayi (Dziewońska and Ostrowska 1978; Waś et al. 1980; Świeżyński et al. 1981). In turn, resistance to PLRV was identified in $2 x$ clone DW 84-1457 (Dziewońska and Waś 1994). In some cases, the resistance was being selected in dihaploids of resistant $4 x$ varieties or breeding lines. The complex virus resistances were subsequently combined with the appropriate agronomic value and other resistances (to wart, nematodes, LB) and finally with the ability to form $2 n$ gametes. This group of selected DPLs served as virus resistance sources for other PL programmes.

\section{Tetraploid Parental Line Breeding}

The directions of TPL breeding varied during the programme depending on needs of the breeding of new varieties. In the years 1965-1995, parental lines for breeding varieties for fodder and general use accounted ca. 30\% of released TPLs, but after 1995, no more were selected. Since the mid-1990s, the growing importance of varieties suitable for processing into chips initiated such direction of TPL breeding. These works were supplemented by the evaluations of general combining ability (GCA) in terms of quality traits, especially the light-coloured chips after cold storage (Domański et al. 2004a; Domański et al. 2004b). All TPLs suitable for processing had at least one parent with positive GCA for light colour of chips (Domański et al. 2002).

The scale of the TPL programme changed over the last 4 decades. Since the initial period of the TPL programme until its full development up to 1990, approximately 60,000 first-year seedlings were grown in the field each year. This number fell to 
15,000 in the 1990 s and to 5000 at the beginning of the twenty-first century. During the above periods, the average numbers of TPLs issued each year decreased from 18 and 27 in the first 2 decades to 9 and 5 in the last 2 decades. Hence, parental line selection started with ca. 3500 seedling lines at the beginning of the programme and gradually decreased to 2500, then 2000 and 1000 seedling lines in subsequent decades. The reason for this decline was the increasingly limited funding of research work.

\section{Resistance Traits}

In practice until the 1990s, the TPL programme was simply the implementation of resistance breeding in its extreme form. The programme focused on resistances to viral pathogens, and resistance to late blight was the other priority. In turn, among the potato viruses, from the beginning in the early 1960s, the most important were PLRV and PVY. PVM was the third virus of agronomic importance in Poland. There was no resistance to PVM in contemporaneously grown varieties, and strong infection pressure with PVM was noted in Poland and Eastern Europe (Kostiw 2002). The fourth virus of interest was PVS. These priorities were in force for over 20 years but changed in the early 1990s, when PLRV began to gradually lose its significance. In contrast, PVY began to spread faster and has created new variants causing increasing problems in seed production up until today (Zimnoch-Guzowska et al. 2013).

The introduction of a resistance into TPLs was preceded by the identification of its sources and subsequent transfer to a more cultivated genetic background. In parallel, there was a period of international exchange of resistance sources with European research centres and the International Potato Center (CIP). The fairly simple genetics underlying the inheritance of most of virus resistances (PVX, PVY, PVM, and PVS) based on major genes helped to introduce these resistances into breeding lines, in various combinations. Since 1989, it has resulted in selection of TPLs having complexes of virus resistance to 4 or 5 viruses (Table 2). The sources of resistance to PVY, PVX, and PVS were the clones of Solanum stoloniferum, S. acaule, and S. tuberosum ssp. andigena, which came from the Max Planck Institute in Köln and the Potato Breeding Institute in Gross Luesewitz, Germany. The sources of extreme resistance to PVY and PVX were also obtained from the Scottish Crop Research Institute collection and from the N.I. Vavilov Research Institute for Plant Industry (VIR), Russia. The extremely PVY-resistant clones of $S$. stoloniferum from VIR had a significant impact on TPL breeding, since they were male fertile in contrast to other resistant clones derived from this species (Flis et al. 2005).

The sources of resistances to PVM and PLRV were identified in the IHAR collection of diploid potatoes, and the response of resistant genotypes has been accurately recognized (see section on "Diploid Parental Lines" in this paper).

The resistance to LB came from breeding lines developed during the programme, which had $S$. demissum or $S$. stoloniferum in their ancestry. With the beginning of twenty-first century, mid-early clones expressing high resistance to LB were found in the diploid parental line programme using $S$. phureja and S. stenotomum. This resistance was successfully transferred to tetraploid breeding lines. Soon in the following years, in diploid clones, the gene Rpi-phul was identified and mapped, and a diagnostic marker linked with the gene was found. Over time, the complexity of created TPLs also increased. TPLs passed on to breeders were characterized for over 30 traits, which 
Table 2 Timetable of releasing TPLs with combined resistances to viruses

Year of releasing TPLs

1968

1977

1980

1985

1989

1993
TPLs with resistance combinations

PVY PVX

PVY PVX PVS

PVY PVX PVS (PLRV)

PVY PVX PVM ${ }^{\#}$ (PLRV)

PVY PVX PVM ${ }^{\#}$ PVS (PLRV)

PVY§ PVX PVM ${ }^{\dagger}$ PVS PLRV

Resistance to viruses (respective gene and source):

PVYgene $R y_{\text {sto }}$ - male sterile $S$. stoloniferum;

PVY ${ }^{\S}$ gene $R y_{f s t o}$ - male fertile $S$. stoloniferum;

PVXgene $R x_{a c l} S$. acaule;

$\mathrm{PVM}^{\#}$ gene $R m-S$. megistacrolobum;

$\mathrm{PVM}^{\dagger}$ gene $G m-S$. gourlayi;

PVS gene Ns-S. tuberosum ssp. andigena;

(PLRV) elevated level of resistance to PLRV from S. tuberosum (various varieties);

PLRV gene PLRV.4-diploid clone DW 84-1457

included resistances to pathogens and pests, like resistance to the five main potato viruses (PVY, PLRV, PVM, PVS, PVX), LB, wart, and nematodes. The complex combinations of resistance traits were outstanding features of TPLs. This complexity was particularly common for viral resistances. More than half of TPLs (53\%) were resistant to two viruses (predominantly to PVY and PVX), 23\% of lines was resistant to three viruses, and $6 \%$ of released TPLs was resistant to five viruses. The most important PVY resistance was present in 96\% of TPLs.

\section{Impact of Parental Line Breeding}

\section{Diploid Parental Lines}

The main role of the diploid material was to support the development of TPLs, and this was very effective. The selected DPLs were of various origin and were donors of a number of important quality features related to cooking and chipping ability and increased tuber starchiness (Domański et al. 2004a, 2004b) along with several resistance traits: resistance to PLRV, PVM (Dziewońska and Waś 1994), wart (Plich et al. 2018), late blight (Śliwka et al. 2006), and bacterial soft rot and blackleg (Lebecka et al. 2004). Thus in 1997, about $70 \%$ of TPLs grown in Młochów originated from diploids.

However, in 1997, the diploid lines were officially given to Polish breeders as actual parental lines, along with the characteristics of the complex of 30 traits (agronomic traits, quality, and resistances) and recommendation for using them in $4 x-2 x$ crosses. Two diploid clones offered, DG. 88-89 and DG. 88-4556, were a source of good suitability for chipping, due to their low accumulation of reducing sugars in tubers stored at low temperatures. However, due to the difficulties in using DPLs in $4 x-2 x$ 
crosses, where seed setting was weaker than in $4 x-4 x$ crosses, breeders preferred to obtain tetraploid progenies of $4 x-2 x$ crosses, rather than DPL clone alone.

The $4 x$ - $2 x$ crosses became an element of testing $2 x$ clones for their ability to form $2 n$ gametes and seed setting efficiency. Furthermore, the $4 x-2 x$ progenies provided evaluations of the $2 x$ clones for their breeding value for specific traits (Domański et al. 2000, Domański et al. 2002). In the mid-1980s, along with $2 x-2 x$ crosses, the $4 x-2 x$ crosses were introduced into crossing programmes. In the period of 10 years, 19962005 , eight $4 x$ - $2 x$ interploid crossing programmes were made with 45 tetraploid parents and 55 tested DPLs (Jakuczun and Wasilewicz-Flis 2006) (Fig. 3). When diploid parents expressed positive GCA effects, tetraploid clones were selected with a higher frequency from $4 x-2 x$ progenies $(7.6 \%)$ than from $4 x-4 x$ progenies $(1.1 \%)$. The selection criteria were applied to the set of morphological and quality traits, yield, and resistance to viruses using the method of independent culling levels (Domański et al. 2000, Domański et al. 2010). Furthermore, in some progenies from $4 x-2 x$ crosses, heterosis effects were found both for the total tuber yield and marketable yield (Domański et al. 2006).

Diploid materials have been used in the Młochów Center in studies on genetic background of the most important features of potato resistance and tuber quality. Genetic studies were conducted on diploids to determine inheritance of chosen quality traits: level of glucose, tuber greening, darkening of cooked tuber flesh, and low accumulation of reducing sugars after cold storage. A significant portion of studies on diploids was directed to the inheritance of resistance to main viruses, late blight, bacterial soft rot, and wart disease.
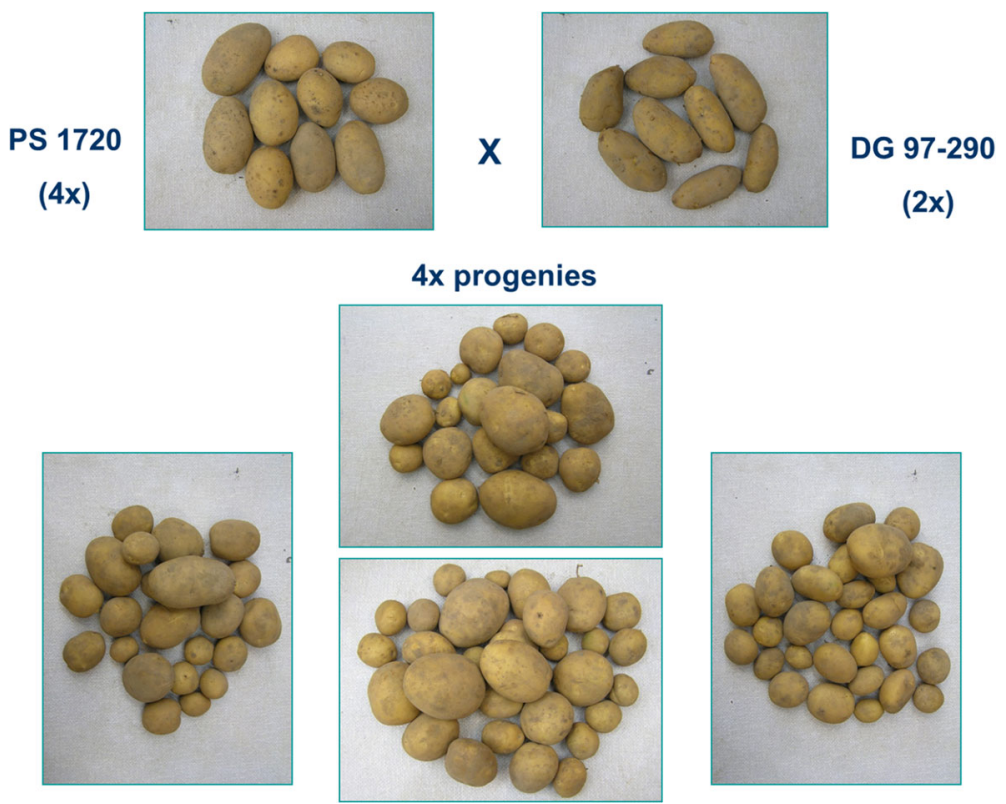

Fig. 3 Tuber appearance of some progeny individuals originating from crossing between tetraploid (PS1720) and diploid (DG97-290) parental lines. PS1720 had good level of cooking and processing quality traits and was resistant to PVY, PVM, PLRV, and wart. DG97-290 had high level of cooking quality combined with resistances to PVX, PLRV, blackleg, and soft rot ( $2 x$ hybrid with 8 Solanum species in the origin) 
Table 3 List of traits studied in potatoes developed in DPL, names of Solanum species exploited, and data on published QTLs/gene localization on the potato genetic maps and their molecular markers

Trait

Resources, Solanum species ${ }^{\#}$

QTL/genes mapped to potato genome at IHAR

Resistance to
$\begin{aligned} & \text { Phytophthora } \\ & \text { infestans }\end{aligned} \quad d m s$, ver, $m c d$, mch, phu, phu-stn, rzc

Potato virus $M$
Potato virus $S$
Potato virus $Y$
Potato leafroll virus
Soft rot
Wart
Quality
Tuber starch content;
leaf sucrose content
Low reducing sugars
after cold storage
Enzymatic
discolouration of
flesh and black spot
bruising
Tuber green

Tuber greening

Tuber dormancy, shape regularity, eye depth, flesh colour

Traits as above and tuber weight

grl, meg

adg

sto, tbr, chc

chc, yun, tbr, dms dms, ver, mcd, phu $t b r$ and input of $c h c, g r l, y u n, v e r$, mcd, phu tbr and input of chc, grl, yun, ver, mcd, phu $t b r$ and input of $a c l, c h c, d m s, v e r$, mcd, grl, yun, phu, stn dms, ver, mcd, phu chc, ver, mcd, grl, yun $d m s, p h u, s t n$ in addition
Complex hybrids with $t b r, c h c, y u n, p h u$

Complex hybrids with predominance of tbr and input of chc, grl, yun, sto, acl,

Complex hybrids with predominance of

Complex hybrids with predominance of

Complex hybrids with predominance of QTLs (Hara- Skrzypiec et al. 2018)

Complex hybrids with predominance of tbr and input of chc, grl, yun, sto, acl,

The 1st set of parents: complex hybrids with predominance of $t b r$ and input of

In the 2nd set of parents input of $\mathrm{acl}$,
QTLs $($ ver $\times$ mcd) (Śliwka et al. 2007); Rpi-phul (Śliwka et al. 2006); Rpi-mch1 (Śliwka et al. 2012a); Rpi-rzcl (Śliwka et al. 2012b)

Gm, Rm (Marczewski et al. 2006)

Ns (Marczewski et al. 2002)

$R y-f_{\text {sto }}$ (Flis et al. 2005); $N y-D G$ (Szajko et al. 2019)

PLRV.1. (Marczewski et al. 2001); PLRV.4. (Marczewski et al. 2004)

QTLs (Zimnoch-Guzowska et al. 2000)

Sen2 (Plich et al. 2018)

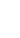

QTLs (Śliwka et al. 2016)

QTLs (Sołtys-Kalina et al. 2020)

QTLs (Plich et al. 2020)

QTLs (Śliwka et al. 2008)

QTLs (Hara-Skrzypiec et al. 2018)

Species abbreviations acc. Huaman and Ross 1985

\# adg-S. tuberosum subsp. andigena, acl-S. acaule, brd-S. brevidens, chc-S. chacoense CPC 3785, GLKS 66.51/6/6, PK 133, dms-S. demissum, gon-S. goniocalyx, grl-S. gourlayi INTA 7330, INTA7356; mcd-S. microdontum WAC 3220, PI 265575; mch-S. michoacanum VIR5763; meg-S. megistracrolobum R.72.554 (MPI); phu-S. phureja Soliman CCC 1.3; rzc-S. ruiz-ceballosi; spg-S. spegazini; sto-S. stoloniferum; tar-S. tarijense; ver-S. verrucosum PI 195170; and CPC 2644, yun-S. yungasense GLKS $67.107 / 3 R$

Since the late 1990s, research on $2 x$ level was focused on the development of a potato genetic map, chromosomal localization of QTLs, and genes for traits of interest and also on molecular (diagnostic) markers for selection. This programme was partly 


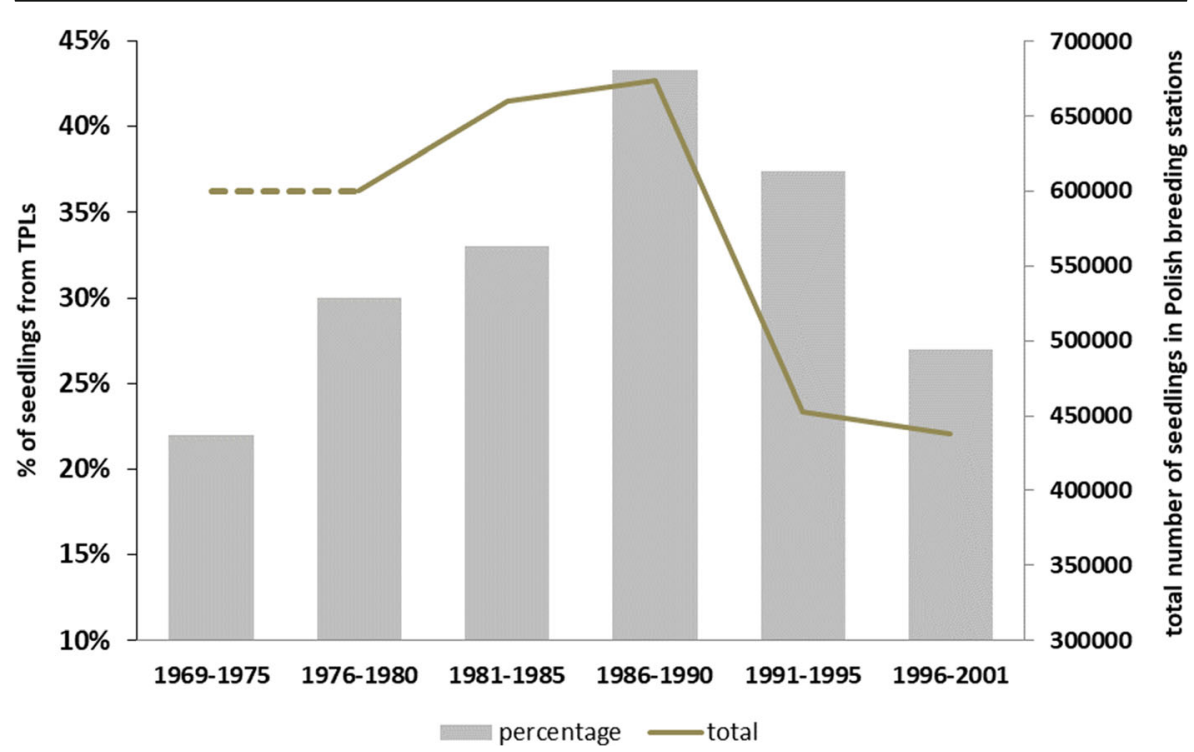

Fig. 4 Participation of seedlings derived from crossing with TPLs in total number of seedlings grown in potato breeding programmes in Poland (dashed line stands for estimated total number of seedlings). Note: Figures are not available after 2001. Since then, Polish breeders have been reluctant to publish data on the scale of their work, as a result of increasing competition from foreign breeding companies

realized in international collaboration to Dr. Christiane Gebhardt from Max Planck Institute. The list of traits studied in diploids, names of Solanum species used, and data on published QTLs/gene localization on the genetic maps and molecular markers found are given in Table 3.

Table 4 List of Polish varieties originated from TPLs (in bold-varieties currently registered in Poland)

\begin{tabular}{|c|c|c|c|}
\hline \multirow[t]{2}{*}{ Type } & \multirow[t]{2}{*}{ Maturity } & \multicolumn{2}{|l|}{ Varieties registered in } \\
\hline & & 1985-1999 & 2000-2019 \\
\hline \multirow[t]{5}{*}{ Table } & Very early & Malwa & Flaming \\
\hline & Early & Aksamitka; Lotos & Eugenia; Korona; Magnolia; Owacja \\
\hline & Mid early & $\begin{array}{l}\text { Barycz; Baszta; Bekas; Tokaj; } \\
\text { Triada; Wigry }\end{array}$ & $\begin{array}{l}\text { Ametyst; Bursztyn; Etiuda; Finezja; } \\
\text { Gardena; Gawin; Jutrzenka; Legenda; } \\
\text { Malaga; Mazur; Tajfun; Wiarus }\end{array}$ \\
\hline & Mid late & Arkadia; Beata; Bogna; Danusia & Gustaw; Niagara; Syrena \\
\hline & Late & Olza & Medea; Soplica; Ursus \\
\hline \multirow[t]{3}{*}{ Starch } & Mid early & Darga; Łucja & $\begin{array}{l}\text { Kaszub; Mieszko; Monsun; Pasat; } \\
\text { Rumpel; Szyper; Widawa }\end{array}$ \\
\hline & Mid late & $\begin{array}{l}\text { Brda; Fregata; Grot; Ikar; Klepa; } \\
\text { Omulew; Vistula }\end{array}$ & Amarant; Pasja Pomorska \\
\hline & Late & $\begin{array}{l}\text { Bzura; Ceza; Dunajec; Ekra; } \\
\text { Hinga; Jantar; Koga; Meduza; } \\
\text { Nimfy }\end{array}$ & $\begin{array}{l}\text { Gandawa; Inwestor; Neptun; Rudawa; } \\
\text { Sonda; Ślęza; Umiak; Wist }\end{array}$ \\
\hline
\end{tabular}




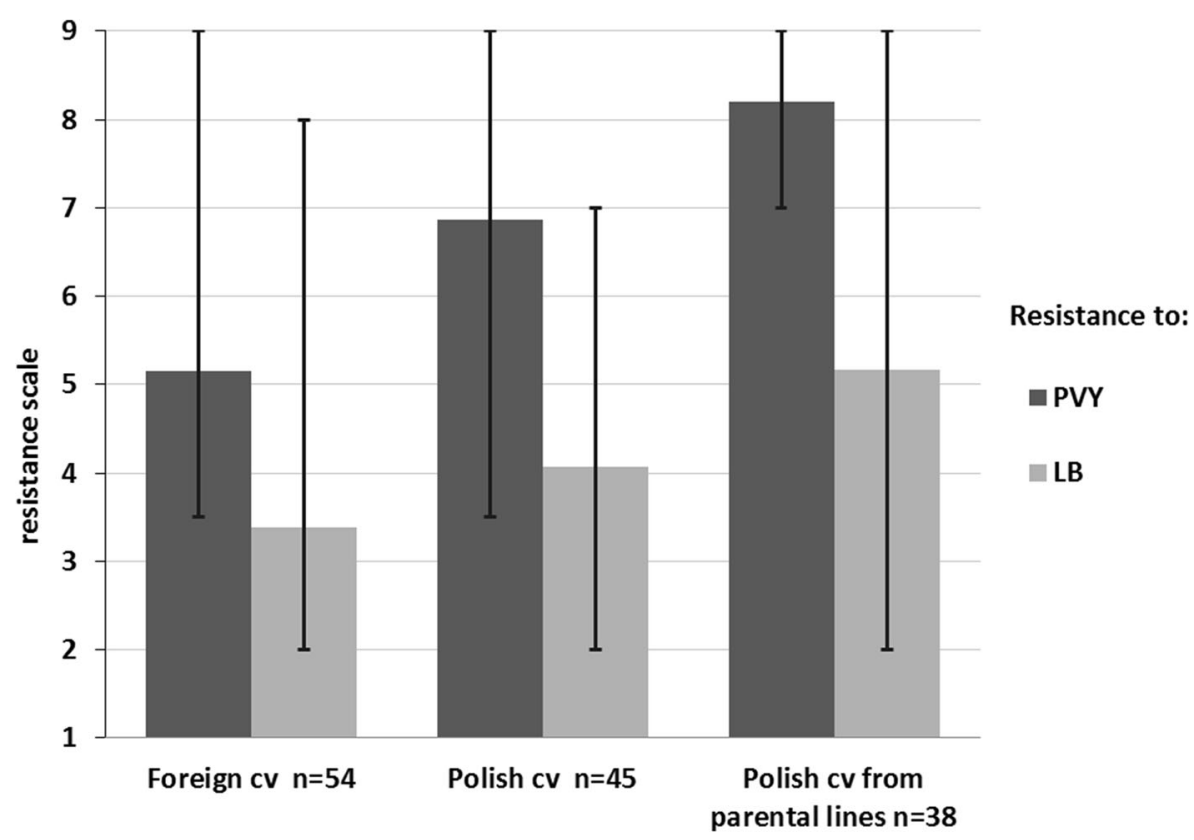

Fig. 5 Resistance to PVY and late blight (LB) in potato varieties registered in Poland for the period 20012010 grouped according to their origin. Bars indicate mean resistance values and whiskers indicate range between minimum and maximum of varieties resistances; resistance scale 1-9, where 9 is the most resistant (acc. Boguszewska et al. 2011)

\section{Tetraploid Parental Lines}

The programme of parental line breeding significantly influenced the breeding pool in Polish potato breeding companies. The impact on variety breeding was marked by both the number of seedlings derived from crosses with TPLs (Fig. 4) and a significant contribution of ca. $35 \%$ of the most advanced breeding lines selected from such seedlings. The programme resulted in the release of 72 varieties in Poland from direct crosses with TPLs (Table 4). In addition to these quantitative effects of the TPL programme on potato breeding, the impact on the genetic composition of varieties released by the breeding companies was equally important. This effect was reflected in the higher level of resistances to LB or PVY that occurs in varieties derived from the TPLs as compared to other registered varieties of non-TPL-related origin (Fig. 5). Also, among varieties from the TPL programme were ones resistant to other viruses such as PVM (e.g., Ametyst, Finezja, Eugenia, Korona), with the gene Rm, whose presence was verified by phenotype evaluation and by the identification of appropriate molecular marker (Chrzanowska et al. 2011). Similarly, in some varieties, the gene Ns conferring resistance to PVS was identified (e.g., Sonda, Ślęza, Tajfun) (Chrzanowska et al. 2011).

The programme of TPL development had a particularly significant impact on breeding of starch varieties. Starch varieties derived from TPL combine a high level of resistance to LB and a very high starch yield, resulting from both high starch content and high tuber yield. In starch varieties registered after 2000, the resistance to LB in 14 originated from TPLs was rated at 6.1, compared with seven Polish varieties and five 
foreign ones at 5.3 and 4.8, respectively (in 9 grade scale, where $9=$ the most resistant). Among the most LB-resistant varieties still currently grown is variety Bzura, which was registered in 1986 and proved its resistance in field experiments performed in locations most exposed to epiphytosis (e.g., Toluca Valley in Mexico). For starch varieties recorded in Polish National List of Agricultural Plant Varieties in 2001-2019, the mean starch yield in TPL-derived varieties was $9.5 \mathrm{t} \cdot \mathrm{ha}^{-1}$ as compared to $9.2 \mathrm{t} \cdot \mathrm{ha}^{-1}$ for other Polish varieties and $8.3 \mathrm{t}^{\mathrm{h}} \mathrm{ha}^{-1}$ in the case of foreign varieties. In this respect, the most outstanding were Sonda (starch yield $\left.10.1 \mathrm{t} \cdot \mathrm{ha}^{-1}\right)$ and Bzura $\left(9.2 \mathrm{t} \cdot \mathrm{ha}^{-1}\right)$. The LBand PVY-resistant starch variety Hinga has been cultivated in Poland and France for years.

From among the various groups of TPLs resulting from targeted selection, the greatest impact on potato breeding in Poland was from TPLs which were evaluated and selected on the basis of field experiments carried out on light soil. These TPLs became the parents of 12 varieties including 6 starch and 6 table ones, including the variety Tajfun which is still recommended for organic farming.

\section{International Exchange}

In the parental line breeding programme, materials from foreign collections or breeding programmes were widely used, which was particularly evident in the 1970s and 1980s. However, the use of foreign materials turned into mutual exchange. Breeding materials created during the programme were used by foreign institutions doing research and breeding. The most important was the cooperation with the International Potato Center (CIP), to which some seed samples and tubers of 22 tetraploid and 8 diploid clones were delivered between 1978 and 1994. All these materials were sources of resistance to viruses and/or LB. In the following years, the Młochów Research Center started cooperation with USDA centres and Cornell University, and this resulted in the delivery of some TPLs to the USA. One of the parents of North American variety Defender was a selection from true seeds obtained from the Młochów Research Center and originated from crossing involving a TPL resistant to viruses and LB.

Single tetraploid parental lines were also passed to Germany, Mexico, and Denmark, while diploid lines were sent to breeders or researchers in Canada, Spain, France, Denmark, and Slovakia.

\section{Concluding Remarks}

The parental line breeding programme was established to help Polish potato breeding after World War II. Parental lines with improved resistances and quality traits were offered annually to the 11 domestic potato breeding stations that existed in the 1970 s to broaden their genetic base. The parental lines themselves were used as resources and not as final products on variety level, as they were outstanding in some features but did not meet all of the criteria of a finished variety, with the exception of variety Bzura. Today, the parental line breeding as described in this paper has been discontinued. The main reason for ending the programme was its high costs and the decreasing importance of potatoes in Polish agriculture. Some breeding work continues, but the development of new breeding lines is being done within the framework of specific projects 
financed from various sources. These breeding lines usually have special features, e.g., elevated carotenoid content in tubers, suitability for organic cultivation, or combined resistances to late blight from different, not-exploited sources.

The diploid and tetraploid gene pool that was created during the parental development programme is the reservoir of various resistance genes as well as genetic factors determining quality traits. This pool is stored as an in vitro collection of the most valuable genotypes or true seeds from their crosses, or is present in breeding lines that are currently grown in the field.

Open Access This article is licensed under a Creative Commons Attribution 4.0 International License, which permits use, sharing, adaptation, distribution and reproduction in any medium or format, as long as you give appropriate credit to the original author(s) and the source, provide a link to the Creative Commons licence, and indicate if changes were made. The images or other third party material in this article are included in the article's Creative Commons licence, unless indicated otherwise in a credit line to the material. If material is not included in the article's Creative Commons licence and your intended use is not permitted by statutory regulation or exceeds the permitted use, you will need to obtain permission directly from the copyright holder. To view a copy of this licence, visit http://creativecommons.org/licenses/by/4.0/.

\section{References}

Boguszewska D, Czerko Z, Goliszewski W, Grudzińska M, Kowalczyk B, Lenartowicz T, Lutomirska B, Michalak K, Nowacki W, Szutkowska M, Trawczyński C, Wierzbicka A, Zarzyńska K, Zagórska H, Zgórska K (2011) Charakterystyka Krajowego Rejestru Odmian Ziemniaka, editions XIV: 15-18 (in Polish)

Chase SS (1963) Analytic breeding in Solanum tuberosum L. A scheme utilizing parthenotes and other diploid stocks. Can J Gent Cyt 5(4):359-363

Chrzanowska M (2001) Evaluation of resistance and reaction of potato cultivars and breeders selections to Potato virus $Y$ (PVY) strains. The methods of evaluation and selection applied in potato research and breeding. In: Zimnoch-Guzowska E, Syller J, Sieczka M (eds) Monografie i Rozprawy Naukowe IHAR nr 10, pp 39-42

Chrzanowska M, Michalak K, Zagórska H, Szajko K (2011) Reakcja na wirusy odmian ziemniaka znajdujących się w Krajowym Rejestrze w 2010 roku. Biul IHAR 260/261:309-324 (in Polish with English summary)

Domański L (2001a) Assessment of morphological characters of potato tubers. The methods of evaluation and selection applied in potato research and breeding. In: Zimnoch-Guzowska E, Syller J, Sieczka M (eds) Monografie i Rozprawy Naukowe IHAR nr 10, pp 92-95

Domański L (2001b) Assessment of cooking quality of potatoes. The methods of evaluation and selection applied in potato research and breeding. In: Zimnoch-Guzowska E, Syller J, Sieczka M (eds) Monografie i Rozprawy Naukowe IHAR nr 10, pp 96-100

Domański L, Domańska M, Jakuczun H (2000) Ocena potomstw i klonów ziemniaka uzyskanych z krzyżowań interploidalnych ( $4 x$-2x). Biul IHAR 216:497-503 (in Polish with English summary)

Domański L, Zimnoch-Guzowska E, Domańska M (2002) Identification of superior parents for potato breeding programmes of new cultivars for processing. Plant Breed Seed Sci 46:79-91

Domański L, Zimnoch-Guzowska E, Domańska M, Jakuczun H, Zgórska K, Mazurczyk-Frydecka A (2004a) The development of cold chipping parental lines for breeding cultivars suitable for processing. Plant Breed Seed Sci 49:91-100

Domański L, Zimnoch-Guzowska E, Flis B, Domańska M, Zgórska K, Frydecka-Mazurczyk A (2004b) Parental line breeding of potato focused on cold chipping. Veg Crops Res Bull 61:29-31

Domański L, Zimnoch-Guzowska E, Domańska M, Jakuczun H (2006) The effect of heterosis of diploid potato clone DG.97-943 of cold chipping type and producing 2n gametes. Biul IHAR 240(241):307-313 (in Polish with English summary) 
Domański L, Flis B, Jakuczun H, Zimnoch-Guzowska E (2010) Variation of processing quality and tuber morphology traits in potato progenies derived from interploid matings 4x-2x. Biul IHAR 257(258):57-69 (in Polish with English summary)

Dziewońska MA, Ostrowska K (1978) Resistance to potato virus M in certain wild potato species. Potato Res 21:129-131

Dziewońska MA, Waś M (1994) Diploid genotype DW.84-1457, highly resistant to potato leafroll virus (PLRV). Potato Res 37:217-224

Flis B (2017) Selection of potato parental lines with complex resistances to potato pathogens and pests. Plant Breed Seed Sci 76:57-63

Flis B, Hennig J, Strzelczyk-Żyta D, Gebhardt C, Marczewski W (2005) The Ry-fsto gene from Solanum stoloniferum for extreme resistant to Potato virus Y maps to potato chromosome XII and is diagnosed by PCR marker GP122718 in PVY resistant potato cultivars. Mol Breed 15:95-101

Hara-Skrzypiec A, Śliwka J, Jakuczun H, Zimnoch-Guzowska E (2018) Quantitative trait loci for tuber blackspot bruise and enzymatic discoloration susceptibility in diploid potato. Mol Gen Genomics 293:331-342

Huaman Z, Ross RW (1985) Updated listing of potato species names, abbreviations and taxonomic status. Am Potato J 62:629-641

Iwanaga M (1982) Breeding at 2x level for combined pest and disease resistance using wild species and extracted haploids from selected tetraploid clones. Rep Plann Conf Util Gen Resources Potato III CIP, Lima 1980:110-124

Jakuczun H, Eising J (2003) Inheritance of after cooking blackening in potato families from $2 x-2 x, 4 x-2 x$ and $4 \mathrm{x}-4 \mathrm{x}$ crosses. Breeding adaptation of potatoes. EAPR Breeding and Varietal Assessment Section. 26-30 July 2003, Oulu, Finland 12

Jakuczun H, Wasilewicz-Flis I (2006) Przenoszenie zmienności genetycznej wybranych cech z ziemniaka diploidalnego na poziom tetraploidalny w IHAR w latach 1996-2005. Zesz Probl Postep Nauk Rol 511: 131-140 (in Polish with English summary)

Jakuczun H, Zimnoch-Guzowska E (2006) Inheritance of tuber greening under light exposure in diploid potatoes. Am J Potato Res 83:211-221

Jakuczun H, Zgórska K, Zimnoch-Guzowska E (1995) An investigation of the level of reducing sugars in diploid potatoes before and after cold storage. Potato Res 38:331-338

Kostiw M (2002) The spread of PVY, PVM, PVS and PLRV at Bonin conditions 1996-1999. J Plant Protect Res 42(2):165-171

Lebecka R (2001) Assessment of resistance to soft rot in whole tubers and in tuber slices. The methods of evaluation and selection applied in potato research and breeding. In: Zimnoch-Guzowska E, Syller J, Sieczka M (eds) Monografie i Rozprawy Naukowe IHAR nr 10, pp 83-85

Lebecka R, Zimnoch-Guzowska E, Kaczmarek Z (2004) Resistance to soft rot (Erwinia carotovora subsp. atroseptica) in tetraploid potato families obtained from 4x-2x crosses. Am J Potato Res 82:107-114

Marczewski W, Flis B, Syller J, Schafer-Pregl R, Gebhardt C (2001) A major QTL for resistance to Potato leafroll virus (PLRV) is located in a resistance hotspot on chromosome XI and is linked to N-gene-likemarkers. Mol Plant-Microbe Interact 14(12):1420-1425

Marczewski W, Hennig J, Gebhardt C (2002) The potato virus S resistance gene Ns maps to potato chromosome VIII. Theor Appl Genet 105:564-567

Marczewski W, Flis B, Syller J, Strzelczyk-Żyta D, Hennig J, Gebhardt C (2004) Two allelic or tightly linked genetic factors at the PLRV.4 locus on potato chromosome XI control resistance to potato leafroll virus accumulation. Theor Appl Genet 109:1604-1609

Marczewski W, Strzelczyk-Żyta D, Hennig J, Witek K, Gebhardt C (2006) Potato chromosomes IX and XI carry genes for resistance to potato virus M. Theor Appl Genet 112:1232-1238

Mendinburu AO, Peloquin SJ (1977) The significance of $2 \mathrm{n}$ gametes on potato breeding. Theor Appl Genet 49:53-61

Pietrak J (2001) Greenhouse assessment of potato resistance to blackleg. The methods of evaluation and selection applied in potato research and breeding. In: Zimnoch-Guzowska E, Syller J, Sieczka M (eds) Monografie i Rozprawy Naukowe IHAR nr 10, pp 86-87

Plich J, Przetakiewicz J, Śliwka J, Flis B, Wasilewicz-Flis I, Zimnoch-Guzowska E (2018) Novel gene Sen2 conferring broad-spectrum resistance to Synchytrium endobioticum mapped to potato chromosome XI. Theor Appl Genet 131:232-2331

Plich J, Zimnoch-Guzowska E, Tatarowska B, Śliwka J (2020) Quantitative trait loci analysis of potato tuber greening. Mol Biol Rep 47:1713-1722

Ross H (1986) Potato breeding - Problems and perspectives. In: Advances in plant breeding. Suppl. 13 to J. Plant Breed, pp 132 
Sieczka M (2001a) Selection of the first year seedlings resistant to PVY, PVX and PVM using gun-spray inoculation. The methods of evaluation and selection applied in potato research and breeding. In: Zimnoch-Guzowska E, Syller J, Sieczka M (eds) Monografie i Rozprawy Naukowe IHAR nr 10a, pp 50-52

Sieczka M (2001b) Evaluation of resistance to Phytophthora infestans under natural infection pressure. The methods of evaluation and selection applied in potato research and breeding. In: Zimnoch-Guzowska E, Syller J, Sieczka M (eds) Monografie i Rozprawy Naukowe IHAR nr 10a, pp 72-74

Śliwka J, Jakuczun H, Lebecka R, Marczewski W, Gebhardt C, Zimnoch-Guzowska E (2006) The novel, major locus Rpi-phul for late blight resistance maps to potato chromosome IX and is not correlated with long vegetation period. Theor Appl Genet 113:685-695

Śliwka J, Jakuczun H, Lebecka R, Marczewski W, Gebhardt C, Zimnoch-Guzowska E (2007) Tagging QTLs for late blight resistance and plant maturity from diploid wild relatives in a cultivated potato (Solanum tuberosum) background. Theor Appl Genet 115:101-112

Śliwka J, Wasilewicz-Flis I, Jakuczun H, Gebhardt C (2008) Tagging quantitative trait loci for dormancy, tuber shape, regularity of tuber shape, eye depth and flesh colour in diploid potato originated from six Solanum species. Plant Breed 127(1):49-55

Śliwka J, Jakuczun H, Chmielarz M, Hara-Skrzypiec A, Tomczyńska I, Kilian A, Zimnoch-Guzowska E (2012a) A new resistance gene against potato late blight originating from Solanum $\times$ michoacanum maps to potato chromosome VII. Theor Appl Gen 124:397-406

Śliwka J, Jakuczun H, Chmielarz M, Hara-Skrzypiec A, Tomczyńska I, Kilian A, Zimnoch-Guzowska E (2012b) Late blight resistance gene from Solanum ruiz-ceballosii is located on potato chromosome X and linked to violet flower colour. BMC Genet 13(1):11

Śliwka J, Sołtys-Kalina D, Szajko K, Wasilewicz-Flis I, Strzelczyk-Żyta D, Zimnoch-Guzowska E, Jakuczun H, Marczewski W (2016) Mapping of quantitative trait loci for tuber starch and leaf sucrose contents in diploid potato. Theor Appl Genet 129:131-140

Sołtys-Kalina D, Szajko K, Wasilewicz-Flis I, Mańkowski D, Marczewski W, Śliwka J (2020) Quantitative trait loci for starch-corrected chip color after harvest, cold storage and after reconditioning mapped in diploid potato. Mol Gen Genomics 295:209-219

Strzelczyk-Żyta D, Jakuczun H, Zimnoch-Guzowska E (1997) Zdolność do tworzenia męskich gamet 2n w diploidalnych klonach ziemniaka z programu syntezy diploidalnych form rodzicielskich. Biul Inst Ziemniaka 48(I):99-105 (in Polish with English summary)

Świeżyński KM (1971) Ogólne zagadnienia syntezy materiałów wyjściowych. Zesz Probl Postep Nauk Rol 118:9-26 (in Polish with English summary)

Świeżyński KM, Zimnoch-Guzowska E (1996) Development of parental lines for Polish potato breeding. J Appl Genet 37A:15-23

Świeżyński KM, Dziewońska MA, Ostrowska K (1981) Inheritance of the resistance to potato virus M found in Solanum gourlayi Haw. Genet Pol 22:1-8

Świeżynski KM, Sawicka E, Van Suchtelen N, Wagenvoort M (1985) Potato (Solanum tuberosum L.) improvement by breeding at the diploid level. Ziemniak - The Potato 5-23

Syller J (2001) A greenhouse evaluation of resistance to Potato leafroll virus (PLRV) using inoculation by aphids. The methods of evaluation and selection applied in potato research and breeding. In: ZimnochGuzowska E, Syller J, Sieczka M (eds) Monografie i Rozprawy Naukowe IHAR nr 10, pp 30-32

Szajko K, Sołtys-Kalina D, Szarzynska B, Strzelczyk-Żyta D, Szweykowska-Kulinska Z, Marczewski W (2019) A comparative proteomic analysis of the PVY-induced hypersensitive response in leaves of potato (Solanum tuberosum L.) plants that differ in Ny-lgene dosage. Eur J Plant Pathol 153:385-396

Wagenvoort M, Zimnoch-Guzowska E (1992) Gene-centromere mapping in potato by half-tetrad analysis: map distance of the $H 1, R x$ and $R y$ and their possible use for ascertaining the mode of $2 \mathrm{n}$ pollen formation. Genome 35:1-7

Waś M, Dziewońska MA, Ostrowska K, Kowalska A (1980) Reaction of Solanum gourlayi and its hybrids with S. tuberosum to potato virus M (PVM). Phytopath Z 97:186-191

Wasilewicz-Flis I (2001) Selection of breeding lines possessing resistance to Potato virus $M$ (PVM) controlled by the $\mathrm{Gm}$ or/and $\mathrm{Rm}$ genes. The methods of evaluation and selection applied in potato research and breeding. In: Zimnoch-Guzowska E, Syller J, Sieczka M (eds) Monografie i Rozprawy Naukowe IHAR nr 10, pp 47-49

Wenzel G, Schieder O, Przewoźny T, Sopory SK, Melchers G (1979) Comparison of single cell culture derived Solanum tuberosum L. plants and a model for their application in breeding programs. Theor Appl Genet 55:49-55

Zarzycka H (2001) Evaluation of resistance to Phytophthora infestans in detached leaflet assay. Preparation of the inoculum. The methods of evaluation and selection applied in potato research and breeding. In: ZimnochGuzowska E, Syller J, Sieczka M (eds) Monografie i Rozprawy Naukowe IHAR nr 10, pp 75-77 
Zimnoch-Guzowska E (2009) Elements of plant breeding and acclimatization institute's strategy for resistance breeding to Phytophthora infestans in Poland. Proceed. of the Third International Late Blight Conference. eds: G.A. Forbes, F. Govers, W. E. Fry, Acta Horticulturae Number 834: 101-110.

Zimnoch-Guzowska E, Dziewońska M (1989) Breeding of potatoes at the diploid level. In: Louwes KM, Toussaint HAJM, Dellaert LMW (eds) Parental line breeding and selection in potato breeding. PUDOC, Wageningen, pp 163-171

Zimnoch-Guzowska E, Lojkowska E (1993) Resistance to Erwinia spp. in diploid potato with a high starch content. Potato Res 36(3):177-182

Zimnoch-Guzowska E, Wasilewicz I (1987) Unreduced gametes in the breeding of potatoes at the diploid level. In: The production of new potato varieties: Technological advances (ed. G.J. Jellis, D.E. Richardson). Cambridge Univ. Press: 222-224

Zimnoch-Guzowska E, Marczewski W, Lebecka R, Schäfer-Pregl R, Salamini F, Gebhardt C (2000) QTL for resistance to Erwinia carotovora ssp. atroseptica in potato are linked to resistance gene like sequences and "hot spots" for resistance to pathogens in the potato/tomato genome. Crop Sci 40(4):1156-1167

Zimnoch-Guzowska E, Yin ZM, Chrzanowska M, Flis B (2013) Sources and effectiveness of potato PVY resistance in IHAR's breeding research. Am J Potato Res 90(1):21-27

Zoteyeva N, Chrzanowska M, Flis B, Zimnoch-Guzowska E (2012) Resistance to pathogens of the potato accessions from the collection of N.I. Vavilov Institute of Plant Industry (VIR). Am J Potato Res 89:277-293

Publisher's Note Springer Nature remains neutral with regard to jurisdictional claims in published maps and institutional affiliations. 